\title{
УДК: 35.08(477)
}

https://doi.org/10.52058/2708-7530-2021-5(11)-130-144

Мельник Володимир Іванович начальник міжрегіонального управління НАДС в Одеській, Миколаївській та Херсонські областях, АРК та м. Севастополь, аспірант кафедри регіональної політики та публічного адміністрування, Одеський регіональний інститут державного управління Національної академії державного управління при Президентові України, м. вул. Генуезька, 22, Одеса, 65009, тел.: (099) 633-86-85, e-mail: V_i_melnik@ukr.net, https://orcid.org/0000-0001-8257-5999

\section{ДЕРЖАВНО-УПРАВЛІНСЬКИЙ АСПЕКТ ГЕНЕЗИ НАУКОВИХ ТЕОРІЙ ТА КОНЦЕПЦЙ У СФЕРІ КАДРОВОГО ЗАБЕЗПЕЧЕННЯ: ВІД УПРАВЛІННЯ ПЕРСОНАЛОМ ДО УПРАВЛІННЯ ЛЮДСЬКИМИ РЕСУРСАМИ}

Анотація. У статті розглянуто ключові наукові теорії та концепції, що сформувалися у сфері управління персоналом, продемонстровано перехід від управління персоналом до управління людськими ресурсами, визначено особливості такого переходу на державній службі. Так, наведено огляд патерналістської концепції, сутність якої мала в своїй основі орієнтир на довічну зайнятість персоналу, таку модель управління персоналом досить часто називають патріархальною. Разом з розглядом концепції патерналізму наведено аналіз низки класичних теорій управління персоналом, низка теорій людських відносин. Також наведено низку концепцій, зокрема школу поведінкових наук, низку мотиваційних теорій. Також наведено іншу позицію, згідно якої у системі управління персоналом за більш ніж сорокарічну історію виділяють два підходи: раціоналістичний, гуманістичний.

Наведено відмінності управління людськими ресурсами від управління персоналом, розкрито місце теорії людського капіталу в управлінні людськими ресурсами.

Зазначено, що сучасний етап характеризується переходом від управління персоналом до управління людськими ресурсами , управління, що займалися просто роботою з кадрами переорієнтовуються на системний менеджмент у сфері людських ресурсів, відтак, досить важливо зосередитися на тому, що ж $\epsilon$ ключовими відмінностями між управлінням персоналом та управлінням людськими ресурсами.

3 теоретичних позицій окреслено концептуальні недоліки управління людськими ресурсами, зокрема визначено, що слабкою ланкою управління людськими ресурсами також $\epsilon$ те, що попри значні ресурсозатрати на підготовку та перепідготовку персоналу, досить часто недостатньої уваги набуває підготовка персоналу, що працюють у кадрових службах, або ж виконують суміжні або допоміжні функції у цій сфері, але не обізнані 3 
практичних тонкощів такої діяльності. Відсутні об'єктивні дані, які свідчать про позитивний вплив впроваджуваної технології управління людськими ресурсами на морально-психологічний клімат в організації.

Визначено, що управління людськими ресурсами на державній службі на сучасному етапі має інтегрувати у собі кращі здобутки усіх етапів розвитку наукових поглядів. Зазначено, що аналізом сучасного стану розвитку управління людськими ресурсами у європейських країнах, можна зробити висновок, що вони є органічним поєднанням теорії раціональної бюрократії М.Вебера, концепції нового публічного менеджменту та належного врядування.

Розкрито наукові підходи до виокремлення специфіки управління людськими ресурсами на державній службі та окреслено ключові принципи, відповідно до кращих світових практик та сучасних наукових положень.

Ключові слова: управління персоналом, державна служба, управління людськими ресурсами, людські ресурси, теоретичні засади, теорії та концепції.

Melnyk Volodymyr Ivanovych Head of the Interregional Department of the National Academy of Public Administration under the President of Ukraine, Genoese St., 22, Odessa, 65009, tel.: (099) 633-86-85, e-mail: v_i_melnik@ukr.net, https://orcid.org/0000-0001-8257-5999

\title{
PUBLIC ADMINISTRATION ASPECT OF THE GENESIS OF SCIENTIFIC THEORIES AND CONCEPTS IN THE FIELD OF HUMAN RESOURCES: FROM PERSONNEL MANAGEMENT TO THE DEPARTMENT OF MANAGEMENT
}

\begin{abstract}
The article considers the key scientific theories and concepts formed in the field of personnel management, demonstrates the transition from personnel management to human resources management, identifies the features of such a transition in the civil service. Thus, an overview of the paternalistic concept, the essence of which was based on the focus on lifelong employment of personnel, such a model of personnel management is often called patriarchal. Along with the consideration of the concept of paternalism, an analysis of a number of classical theories of personnel management, a number of theories of human relations. There are also a number of concepts, including the school of behavioral sciences, a number of motivational theories. There is also another position, according to which in the system of personnel management for more than forty years there are two approaches: rationalist, humanistic.

The differences between human resources management and personnel management are presented, the place of the theory of human capital in human resources management is revealed.

It is noted that the current stage is characterized by the transition from personnel management to human resource management, management, simply engaged in human resources are refocused on system management in the field of
\end{abstract}


human resources, so it is important to focus on what are the key differences between personnel management and management human resources.

From a theoretical point of view, the conceptual shortcomings of human resource management are outlined, in particular, it is determined that the weak link of human resource management is that despite significant resource costs for staff training and retraining, training of personnel working in personnel services is performed. related or auxiliary functions in this area, but not aware of the practical intricacies of such activities. There are no objective data that indicate a positive impact of the implemented human resource management technology on the moral and psychological climate in the organization.

It is determined that the management of human resources in the civil service at the present stage should integrate the best achievements of all stages of development of scientific views. It is noted that the analysis of the current state of human resources management in European countries, we can conclude that they are an organic combination of the theory of rational bureaucracy $M$. Weber, the concept of new public management and good governance.

Scientific approaches to highlighting the specifics of human resources management in the civil service are revealed and key principles are outlined, in accordance with the best world practices and modern scientific provisions.

Keywords: personnel management, civil service, human resources management, human resources, theoretical principles, theories and concepts.

Постановка проблеми. Метою реформування сучасної державної служби в Україні є створення професійної, престижної, авторитетної, політично неупередженої, відповідальної, стабільної, високоефективної, державної служби, яка здатна надавати якісні публічні послуги громадянам. Окреслена мета не може бути досягнена без якісної трансформації системи управління людськими ресурсами (далі - УЛР) на державній службі, оскільки професійність останньої забезпечується саме належним рівнем управлінських стандартів та методів у сфері УЛР.

По суті, значимість людських ресурсів для ефективної реалізації державної політики, здійснення публічного управління $є$ ключовою, адже саме від них залежить якість виконуваних процедур, забезпечення реалізації низки функцій, які на пряму позначаються на житті суспільства, починаючи від мешканців окремої громади і закінчуючи добробутом всієї країни.

За часів незалежності все більше загострилася проблема навколо престижу державної служби, адже рівень заробітної плати та соціальних гарантій не надав змогу забезпечити привабливість усіх ланок посад державної служби на ринку праці. В умовах же необхідності забезпечення системи державного управління висококваліфікованими кадрами проблема престижу та можливості приваблювати висококваліфікованих кадрів також стоїть досить гостро. Саме тому, на наш погляд варто приділяти значну увагу розвитку системи УЛР, адже саме у контексті цієї концепції яскраво прослідковуються не лише вектори забезпечення привабливості посад, а й шляхи професійного зростання на публічній службі, що прямо позначається 
на функціонуванні системи публічного управління.

Нині реформування системи УЛР здійснюється задля приведення в більш конкурентоспроможний вигляд окремих складових системи державної служби, тоді як таке реформування передбачає різноманітні зрушення та перетворення задля осучаснення, вдосконалення, а також наближення до максимального з можливих рівнів розвитку.

Аналіз останніх досліджень і публікацій. Серед вітчизняних учених, які займаються проблемами, дотичними до управління людськими ресурсами на державній службі, великого значення в нашій роботі набули роботи Т. Василевської, С. Газарян, Н. Гончарук, С. Липовської, О. Мельникова, В. Олуйка, О. Пархоменко-Куцевіл, Т. Пахомової, Л. Пашко, А. Рачинського, В. Рижих, С. Серьогіна, А. Сіцінського, I. Сурай, С. Хаджирадєвої, та ін. Значну увагу переліченими дослідниками приділено теоретикометодологічним та практико-прикладним засадам процедур планування задля комплектації штатів та персоналу органів публічної влади, розробленню плану задоволення прогнозованих потреб у людських ресурсах.

Науковим підгрунтям статті стали також концептуальні положення класиків управлінського вчення А. Файоля, Ф. Тейлора, М. Вебера, Л.Урвіка, Г.Форда, Е.Мейо, Р.Лікарта, Р.Блейка, Ж.Фрідмана, А.Маслоу, Ф. Гецберга, Д.Макгрегора. Саме їх праці сформували наукове підгрунтя сучасного етапу розвитку наукового вчення у сфері управління людськими ресурсами.

Проте практична значущість предметного ж поля дослідження актуалізує детальний розгляд теоретичних та концептуальних основ переходу від управління персоналом до управління людськими ресурсами.

Відтак, метою статті $\epsilon$ розкриття державно-управлінського аспекту генези наукових теорій та концепцій від управління персоналом до управління людськими ресурсами.

Виклад основного матеріалу. Розпочнемо 3 аналізу витоків сучасних ідей управління людськими ресурсами та їх трансформацій за останні десятиріччя. Аналізуючи ключові етапи розвитку наукових підходів до управління людськими ресурсами в цілому (не лише на державній службі), зазначимо, що теорією, яка домінувала у 40-х - 70-х роках минулого століття була патерналістська концепція [1]. Сутність цієї концепції мала в своїй основі орієнтир на довічну зайнятість персоналу, таку модель управління персоналом досить часто називають патріархальною. Ключовими рисами тут було те, що система стимулів працювала на користь тих, хто буде віддано працювати в окремій установі чи організації, мобільність за такої моделі майже нівелюється, при цьому на перший план виходить ідейність, відданість справі, довіра до керівництва. За своєю суттю концепція патерналізму - це ідеологія та практика управління людьми (адже досить часто мова не лише про професійну діяльність, а й про окремі сфери особистого життя), особлива форма управління в установі чи організації, за якої керівництво ототожнюється 3 «батьком», а підлеглі 3 «синами», які повинні бути вдячними за опіку та підтримку, що повинно проявлятися у відданості, слухняності та ентузіазмі у роботі. Така концепція, зародившись 
ще у VI - V ст. до н.е. в Китаї, була домінуючою у США (у 20-х роках XX ст.), Японії (частково існує і сьогодні, зокрема у практиці пожиттєвого найму, відданості організації тощо), притаманною вона також була для радянського періоду. Разом з тим, така модель досить слабко корелюється 3 основами ринкової економіки та рідко притаманна сучасному етапу розвитку концепцій управління людськими ресурсами, відтак, iï елементи нас цікавитимуть саме з позицій розгляду кар'єрного зростання та планування кар'єри у сучасних умовах.

Слабкістю цієї моделі управління персоналом є їі статичність, що в свою чергу, досить часто гальмує персонал у саморозвитку та здатності підтримувати власну конкурентоспроможність.

Разом $з$ розглядом концепції патерналізму доцільно згадати і низку класичних теорій управління персоналом, так до класиків у досліджуваному аспекті відносять А. Файоля, Ф. Тейлора, М. Вебера, Л.Урвіка, Г.Форда. класичні теорії активно розвивалися та практично реалізовувалися у 18801930-х роках, однак елементи, що викристалізувалися у той час стали підвалинами для наступних етапів розвитку наукових теорій у сфері роботи 3 кадрами. Ключовими тезами класичного етапу розвитку наукових теорій у сфері управління персоналом є:

- необхідність наявності чіткої системи контролю за співробітниками;

- функція керівництва - чітка алгоритмізація дій, розробка процедур, легких та зрозумілих до виконання;

- ключове заохочення - заробітна плата.

При цьому очевидною слабкістю зазначеного періоду $\epsilon$ розгляд працівника як досить пасивного виконавця, однак багато 3 принципів класичної бюрократії є основою для розвитку і сучасного етапу управління персоналом. Так, класична «веберівська» бюрократія на сучасному етапі розглядається як «неовеберівська», коли на класичний каркас принципів нашарувалися ще додаткові новітні елементи, що відображають поєднання виконавської дисципліни, креативності та ініціативності.

Наступним етапом розвитку наукової думки є низка теорій людських відносин, що почали активно формуватися та розвиватися 3 30-х років XX ст., до лав іï представників відносять Е.Мейо, Р.Лікарта, Р.Блейка, Ж.Фрідмана. В ключі зазначених теорій організація розглядається як окремий елемент соціуму, де наявна низка внутрішніх соціальних комунікацій, які існують як між окремими індивідами, так і у групі, в цілому. Важливий акцент у зазначеному ключі на неформальній складовій відносин та на наявні в колективі правила поведінки. Ключовими відмінностями цього етапу є:

- акцент на неформальній мотивації, коли не заробітна плата, а визнання у колективі вважається більшою мотивацією;

- роль керівника зміщується 3 простої алгоритмізації дій та контролю у бік включення працівників до діяльності організації, долучення їх до вирішення справ та проблем, своєрідна протоформа корпоративної культури; 
- відносна самостійність працівників;

- акцент на усвідомленні індивідуальної значущості, що сприятиме спрощенню комунікації 3 керівництвом, підвищенню самодисципліни та $є$ джерелом мотивації.

Наступним етапом еволюціонування наукових підходів можна вважати низку концепцій людських ресурсів, що почали формуватися у 70-х роках минулого сторіччя. Основоположниками зазначених концепцій вважають А.Маслоу, Ф. Гецберга, Д.Макгрегора. характерною особливістю тут $\epsilon$ людиноцентризм. Саме на цьому історичному етапі еволюціонування наукових концепцій вперше почали розглядати співробітника як особистість, вести мову про мотивацію персоналу (мова про не матеріальну), його потреби, необхідність самореалізації тощо. Характерним є те, що з'являється окрім вертикального, ще й горизонтальний вимір взаємовідносин 3 персоналом, кадрові служби стають більш децентралізованими, розширюються їх функції, кадрове забезпечення починають розглядати як значущий ресурс для реалізації діяльності організації, а отже, з'являється усвідомлення цінності та необхідності його розвивати. Також важливим $\epsilon$ поява елементів планування кар'єрного зростання, як елементу мотивації та розвитку персоналу. Значної уваги приділяють корпоративній культурі, гармонізації внутрішнього середовища організації та конкурентного зовнішнього середовища. Важливим у зазначеному ключі є переорієнтація у розгляді кадрового забезпечення 3 суто статті витрат, яку необхідно мінімізувати у бік розгляду як ресурсу, інвестування у розвиток якого може приносити додатковий прибуток. Відтак, з'являється ще один напрям у руслі зазначеного концепту - теорія людського капіталу [2].

На сучасному етапі теорія людського капіталу вийшла на перший план, а в ii рамках кадрове забезпечення розглядають як основний фактор економічного зростання; ресурсозатратне, але необхідне для розвитку, адже саме інвестиції в людський капітал сприяють підвищенню ефективності діяльності; людський капітал $є$ більш динамічним та персоніфікованим, невіддільним від його носія - окремої людини; важливе значення приділяється зацікавленості працівників та способам мотивації.

Широкого практичного впровадження та розповсюдження УЛР почало набувати у 90-х роках XX ст., найчастіше у науковій літературі використовують англомовний еквівалент, тобто говорять про HR менеджмент, але ми в рамках нашого дослідження вестимемо мову про УЛР [3]. Отож, узагальнюючи теоретико-прикладні аспекти, що наявні у науковій літературі, зазначимо ключові особливості УЛР (див. Таблиця 1).

Табличя 1

\section{Ключові особливості УЛР}

\begin{tabular}{|c|c|}
\hline Автор & Підхід \\
\hline Фобрум, Тиші (1984 р.) & $\begin{array}{l}\text { УЛР необхідне для приведення у відповідність } \\
\text { формальної структури та наявних трудових ресурсів, } \\
\text { що надасть змогу досягнути поставленого } \\
\text { стратегічного курсу. Ключовими аспектами УЛР є } \\
\text { відбір, мотивація, винагорода, оцінка, розвиток. }\end{array}$ \\
\hline
\end{tabular}




\begin{tabular}{|l|l|}
\hline $\begin{array}{l}\text { Торрінгтон та Холл } \\
(1987 \text { р. })\end{array}$ & $\begin{array}{l}\text { УЛР спрямовано на забезпечення управлінських } \\
\text { потреб у кадрових ресурсах. Ключовий акцент тут на } \\
\text { таких аспектах як моніторинг, планування. }\end{array}$ \\
\hline Гест (1987 р.) & $\begin{array}{l}\text { УЛР корелюється з гнучкістю, якістю, лояльністю } \\
\text { персоналу. }\end{array}$ \\
\hline Дж. Сторі & $\begin{array}{l}\text { УЛР розглядється як стратегічний вимір розвитку } \\
\text { трудових ресурсів, максимізація використання } \\
\text { наявних людських ресурсів в організації. УЛР } \\
\text { альтернативним способом управління персоналом. }\end{array}$ \\
\hline
\end{tabular}

Складено автором на основі $[4,5]$

Окрім зазначених теорій та концепцій можна визначати i iнші, наприклад школу поведінкових наук, низку мотиваційних теорій тощо, але в рамках нашого дослідження розглянемо також дещо іншу позицію, згідно якої у системі управління персоналом за більш ніж сорокарічну історію виділяють два підходи [6]:

- раціоналістичний, якому притаманний високий ступінь адаптованості організації до конкурентного середовища забезпечується гнучкістю управління персоналом, інтенсифікацією праці висококваліфікованих працівників та участі працівників у розподілі прибутків.

- гуманістичний, за якого відповідальність за створення конкурентних переваг покладається на самих працівників, їх же залучення в справи організації досягається за рахунок таких чинників, як ефективна організаційна комунікація, висока мотивація і гнучке керівництво.

За традиційного раціоналістичного підходу в УЛР за умови що організація інвестує в кадри, вдосконалює технології відбору персоналу, систематично організовує його навчання та реалізує програми кар'єрного зростання, належним чином платить та піклується про персонал, то вона вправі вимагати від своїх працівників лояльності та відповідального ставлення до роботи [7]. Активна кадрова політика забезпечується представництвом керівника кадрової служби в правлінні організації i націлена на задоволення потреб організації в лояльною, стійко функціонуючої i задоволеною своїм становищем робочою силою. Така кадрова політика є основою для реалізації успішної, конкурентоспроможної стратегіï i будується на відміну від традиційних методів управління персоналом не на підпорядкуванні волі роботодавця працівників, а на взаємному врахуванні інтересів сторін і взаємної відповідальності.

Другий же - гуманістичний підхід - в УЛР є певним компромісом між двома напрямками - управлінням персоналом та УЛР [8]. Перетворення працівників у власників підприємства переводить відносини «роботодавець найманий працівник» на новий рівень. Завдяки цьому задоволення багатьох потреб працівників стає метою кадрової політики, а не засобом для досягнення інших цілей, як це мало місце за інших підходів.

Як наслідок, взаємна відповідальність сторін забезпечуватиме наростаючу ефективність діяльності організації. Високий рівень участі 
працівників у проектуванні робочих місць і управлінні якістю умов праці, продукції та послуг створює абсолютно нову атмосферу в організації. Визнання законності різних інтересів працівників відкриває реальні перспективи для залучення їх в процес спільного прийняття управлінських рішень, взаємних консультацій, а також доступу до інформації про справи організації, в якій вони працюють [9].

Таким чином, можна вести мову про певний синтез, що базується на технології УЛР традиційних та сучасних підходів. Разом з тим, увібравши в себе низку переваг різних теорій, концепцій та підходів, що склалися історично УЛР не є «панацеєю» від усіх проблем, вона також має свої недоліки.

Так, критичний аналіз практики УЛР демонструє значний розрив між ідеологічними установками та їх практичною реалізацією. Практика управління людськими ресурсами в різних країнах не тільки відображає різноманіття національних шкіл і традицій, але, швидше, свідчить про відсутність якоїсь єдиної концепції, так як строкатість використовуваних концептуальних схем нерідко ускладнюється їх взаємної суперечливістю. Наприклад, несумісними на практиці подаються такі елементи УЛР, як командна робота та індивідуальна оплата праці в залежності від його ефективності.

Слабкою ланкою УЛР також є те, що попри значні ресурсозатрати на підготовку та перепідготовку персоналу, досить часто недостатньої уваги набуває підготовка персоналу, що працюють у кадрових службах, або ж виконують суміжні або допоміжні функції у цій сфері, але не обізнані 3 практичних тонкощів такої діяльності [10]. Відсутні об'єктивні дані, які свідчать про позитивний вплив впроваджуваної технології управління людськими ресурсами на морально-психологічний клімат в організації.

УЛР можна вважати ефективним, за дотримання таких умов:

- здійснення індивідуального планування кар'єри, підготовки та перепідготовки персоналу, стимулювання професійного росту i ротації кадрів;

- використання гнучких систем організації робіт, автономних робочих груп;

- наявність системи оплати праці, що побудована на принципах врахування індивідуального вкладу та рівня професійної компетенції працівників;

- використання високого рівня участі працівників та робочих груп у розробці та прийнятті управлінських рішень;

- здійснення практики делегування повноважень підлеглим.

Сучасний етап характеризується переходом від управління персоналом до управління людськими ресурсами, управління, що займалися просто роботою з кадрами переорієнтовуються на системний менеджмент у сфері людських ресурсів, відтак, досить важливо зосередитися на тому, що ж $є$ ключовими відмінностями між управлінням персоналом та управлінням людськими ресурсами. 
Ключовою особливістю та відмінністю управління персоналом від управління людськими ресурсами $є$ те, що останнє переорієнтовано з потреб працівників на потреби самої організації в робочій силі, відтак пріоритети управління кадрами визначаються насамперед результатами функціонального аналізу наявних та необхідних робочих місць, тобто реальній потребі у людських ресурсах, а не наявним кадровим потенціалом. По суті своїй, має місце ресурсний підхід, відтак при управлінні людськими ресурсами, кадри розглядаються як один 3 ключових ресурсів системи державного управління, відтак робота над забезпеченням їх кількісноякісного складу виходить на перший план.

Наступною відмінністю УЛР $є$ те, що воно має стратегічний вимір, що перетворює роботу 3 кадрами на більш активну, тоді як управління персоналом, здебільшого, можна вважати реактивним, а подекуди навіть пасивним або ж суто формальним [10]. В зазначеному контексті важливого значення набуває питання відповідальності у роботі з кадрами, так у системі УЛР найчастіше така відповідальність $є$ персоніфікованою та активність діяльності повинна бути забезпечена керівниками відповідних кадрових служб, або відповідальними працівниками, що також забезпечує системність такої роботи, адже утворюється певна інтегрована система кадрового менеджменті, яка власне і реалізує таку проактивну діяльність 3 управління людськими ресурсами в органах публічної влади.

Наступною важливою особливістю УЛР $є$ те, що в ії основі лежить персоніфікований підхід, орієнтований на індивіда, а не на увесь колектив. Тут варто зупинитися детальніше, адже, робота над розвитком зв'язків в колективі, згуртування тощо також є складовою діяльності в рамках УЛР, однак, акцент зроблено на тому, що кожен працівник має власні потреби, можливості, сильні та слабкі сторони, відповідно до яких у рамках УЛР здійснюється планування кар'єрного зростання, підвищення кваліфікації, проходження необхідних тренінгів та курсів, навіть занять 3 психологічного розвантаження, які досить часто $\epsilon$ вкрай потрібними державним службовцям, які займаються діяльністю, пов'язаною 3 прийомом громадян, розглядом звернень, або ж є адміністраторами ЦНАПів.

Ще однією суттєвою відмінністю УЛР від управління персоналом є те, що система управління персоналом мала на меті скоротити витрати на кадрове забезпечення, тоді як в УЛР ключовою $є$ економічна ефективність використання таких коштів, тобто максимізація співвідношення ресурсозатрат та реально отриманих результатів, що можуть виражатися як у зростанні продуктивності праці, так і в підвищенні якості обслуговування населення, якості управлінських рішень, так i в перманентному професійному приростові працівників та підвищенню якості умов праці.

Якщо в управлінні персоналом вся увага зосереджена виключно на рядових працівниках, то за УЛР акцент зміщується на управлінський штат, адже саме компетентність управлінців є ключовим елементом кадрового потенціалу органу публічної влади.

Також за УЛР важливого значення набувають: 
- сильна адаптивна корпоративна культура;

- стимулююча атмосфера взаємної відповідальності як найманого працівника, так і роботодавця;

- прагнення усіх працівників до підвищення ефективності власної діяльності за рахунок підтримки ініціативи на всіх рівнях;

- постійні технічні та організаційні нововведення;

- відкрита комунікація.

Відтак, 3 позицій людиноцентричного підходу відмінності між управлінням персоналом та УЛР відображено у таблиці 1.

Таблищя 2

Відмінності між управлінням персоналом та управлінням людськими ресурсами 3 позицій людиноцентричного підходу

\begin{tabular}{|c|c|}
\hline Управління персоналом & $\begin{array}{c}\text { Управління людськими } \\
\text { ресурсами }\end{array}$ \\
\hline $\begin{array}{c}\text { Працівник як фактор } \\
\text { виробництва }\end{array}$ & $\begin{array}{c}\text { Працівник як індивід та } \\
\text { унікальна складова реалізації цілей } \\
\text { ОПВ }\end{array}$ \\
\hline Працівник як джерело витрат & Працівник як джерело \\
доходів/підвищення якості надаваних \\
послуг
\end{tabular}

Якщо ж узагальнити усі особливості УЛР та відмінності від управління персоналом, то отримаємо результати, що представлені у таблиці 2

Таблиця 3

Відмінності управління людськими ресурсами та управління персоналом в системі публічного управління

\begin{tabular}{|l|l|l|l|}
\hline \multicolumn{1}{|c|}{ № } & \multicolumn{1}{|c|}{$\begin{array}{c}\text { Критерї̈ для } \\
\text { порівняння }\end{array}$} & \multicolumn{1}{|c|}{$\begin{array}{c}\text { Управління } \\
\text { персоналом } \\
\text { Управління } \\
\text { людськими } \\
\text { ресурсами }\end{array}$} \\
\hline 1. & Ресурси & Фізичні та грошові & $\begin{array}{l}\text { Людські, фізичні та } \\
\text { грошові }\end{array}$ \\
\hline 2. & Витрати на персонал & Поточні витрати & Стратегічні інвестиції \\
\hline 3. & Залучення персоналу & Грошові стимули & $\begin{array}{l}\text { Кар’єрне та } \\
\text { професійне зростання, } \\
\text { можливість навчання }\end{array}$ \\
\hline 4. & Витрати на & Мінімальні & Виходять 3 позиції \\
\hline
\end{tabular}




\begin{tabular}{|c|c|c|c|}
\hline & $\begin{array}{l}\text { професійну } \\
\text { підготовку та } \\
\text { підвищення } \\
\text { кваліфікації } \\
\end{array}$ & & $\begin{array}{l}\text { ефективності, } \\
\text { максимальної } \\
\text { корисності }\end{array}$ \\
\hline 5. & $\begin{array}{l}\text { Види та форми } \\
\text { навчання }\end{array}$ & $\begin{array}{l}\text { Здебільшого без } \\
\text { відриву від } \\
\text { виробництва }\end{array}$ & $\begin{array}{l}\text { Всі доступні форми } \\
\text { навчання }\end{array}$ \\
\hline 6. & $\begin{array}{l}\text { Соціальна } \\
\text { інфраструктура }\end{array}$ & Слабка або відсутня & $\begin{array}{l}\text { Виходить з позиції } \\
\text { ефективності, } \\
\text { максимальної } \\
\text { корисності }\end{array}$ \\
\hline 7. & Стиль керівництва & Авторитарний & $\begin{array}{l}\text { За принципом } \\
\text { ситуативності }\end{array}$ \\
\hline 8. & $\begin{array}{l}\text { Регламентація } \\
\text { діяльності }\end{array}$ & Жорстка & $\begin{array}{l}\text { Жорстка з позицій } \\
\text { виконавської } \\
\text { дисципліни, однак } \\
\text { стимулююча з позицій } \\
\text { ініціативності }\end{array}$ \\
\hline 9. & Мотивація & $\begin{array}{l}\text { Індивідуальні } \\
\text { матеріальні стимули, } \\
\text { слабко дієві } \\
\text { нематеріальні } \\
\text { заохочення (досить } \\
\text { часто безсистемні та } \\
\text { недостатньо } \\
\text { обгрунтовані) }\end{array}$ & $\begin{array}{l}\text { Поєднання } \\
\text { економічних та } \\
\text { морально- } \\
\text { психологічних } \\
\text { стимулів, мотивування } \\
\text { високого рівня }\end{array}$ \\
\hline 10. & Строки планування & Короткотермінове & $\begin{array}{l}\text { На весь трудовий цикл } \\
\text { людських ресурсів } \\
\text { (наближено до } \\
\text { стратегічного виміру) }\end{array}$ \\
\hline 11. & $\begin{array}{l}\text { Функції кадрових } \\
\text { служб }\end{array}$ & $\begin{array}{l}\text { Здебільшого облік } \\
\text { персоналу }\end{array}$ & $\begin{array}{l}\text { Переважно аналітичні } \\
\text { та організаційні }\end{array}$ \\
\hline
\end{tabular}

Попри наявність очевидних переваг УЛР, варто враховувати, що вона $\epsilon$ ефективною, досить часто може забезпечувати навіть синергетичний ефект, але за дотримання низки умов:

- відносно добре розвинена система адаптації до зовнішнього i внутрішнього ринку праці (індивідуальне планування кар'єри, підготовка і перепідготовка персоналу, стимулювання професійного зростання і ротації кадрів);

- наявності гнучкої системи організації робіт;

- використання системи оплати, побудованої на принципах всебічного врахування персонального внеску та рівня професійної компетентності, за результативними показниками діяльності; 
- підтримка достатньо високого рівня участі окремих працівників та робочих груп у розробці та прийнятті управлінських рішень, що стосуються їх повсякденної роботи;

- застосування практики делегування повноважень підлеглим;

- функціонування розгалуженої системи організаційної комунікації, що забезпечує дво- і багатосторонні вертикальні, горизонтальні та діагональні взаємозв'язки всередині ОПВ.

Побудова системи державного управління України на основі європейських принципів та необхідність ефективного УЛР в царині державної служби інтенсифікують розроблення i проектування різних варіантів упровадження інноваційних підходів щодо розвитку служби управління персоналом органу публічної влади.

Ведучи мов у про специфіку УЛР на державній службі, варто зосередити увагу на принципах оновлення сучасних систем державного управління, запропонованих Д. Осборном та Т. Геблером, що по суті і відображають сутність застосування УЛР в системі державного управління:

- конкуренція у сфері публічних послуг;

- громадський контроль;

- оцінювання за результатами (а не ресурсозатратами або зусиллями);

- наявність альтернатив для споживачів;

- управління за цілями, а не суто за правилами;

- попередження виникнення проблем (альтернатива управління ризиками);

- децентралізація та деконцентрація в організації, взаємодопомога, а не конкуренція (мова про внутрішнє середовище органу публічної влади);

- перевага ринкових, а не бюрократичних регуляторів;

- орієнтація на вирішення назрілих проблем та задоволення потреб представників всіх трьох секторів [11].

По суті своїй, УЛР на державній службі на сучасному етапі має інтегрувати у собі кращі здобутки усіх етапів розвитку наукових поглядів. За аналізом сучасного стану розвитку УЛР у європейських країнах, можна зробити висновок, що вони є органічним поєднанням теорії раціональної бюрократії М.Вебера, концепції нового публічного менеджменту та належного врядування [12], саме ці концепції є основою також розвитку систем публічного управління розвинених країн світу.

Узагальнюючи здобутки УЛР у системі публічного управління європейських країн, можна виокремити такі ознаки УЛР:

- конкурентний відбір, що здійснюється на основі професійної кваліфікації, досвіду, компетенцій;

- забезпечення відповідності кількісно-якісного складу державних службовців реальним суспільним потребам;

- усвідомлення необхідності врахування неформальної структури суспільства: правил, норм, інституційної пам'яті;

- орієнтація на результат у системі державної служби; 
- лояльність та чітка підзвітність;

- персоналізація відповідальності;

- формування ціннісної основи, дотримання етичних норм та належного морального образу державного службовця;

- інвестування у розвиток людських ресурсів на державній службі [13].

Висновки. Вважаємо, що реформування державної служби має бути системним процесом, що акумулює зрушення та перетворення, які у сукупності сприятимуть переходу системи державної служби в Україні від «традиційної» моделі до динамічної та сучасної, що дотягатиметься за рахунок постійного якісного вдосконалення, як у правових, так і у етичних, організаційних, соціальних, економічних, інституційних, політичних та інших аспектах. За своєю суттю видозміна системи управління персоналом та переорієнтація на УЛР має стати основою для здійснення прогресивного процесу комплексного реформування вітчизняної системи державної служби, що здійснюватиметься як за рахунок трансформації окремих інституцій, так і за рахунок видозміни усієї системи. Такий процес супроводжується як структурними змінами, так і трансформацією функцій, форм, технологій, методів, способів та інструментів управлінської діяльності у системі УЛР на державній службі. Цей процес спрямований на реалізацію нових цілей, стратегій, завдань, пріоритетів, набуття якісно нового рівня розвитку, наближення до максимізації рівня розвитку, адаптації вітчизняної системи державного управління до європейських цінностей та стандартів.

Перспективами подальших наукових досліджень $є$ окреслення значення компетентісного підходу в управлінні людськими ресурсами на державній службі, аналіз практики УЛР на державній службі в Україні.

\section{Лimepamypa:}

1. Балабанова Л. В. Управління персоналом: підручник / Л.В. Балабанова, О.В. Сардак. - Київ: ЦУЛ, 2011. - 468 с.

2. Плячкайтене И. М. Становление и развитие теории человеческого капитала. / И.М. Плячкайтене // Молодой ученый. - 2011. - № 7, т. 1. - С. 102-104

3. Дейв Ульрих. Эффективное управление персоналом: новая роль НRменеджера в организации / Дейв Ульрих. - М.: «Вільямс», 2006. - 304 с.

4. Армстронг Майкл. Стратегическое управление человеческими ресурсами. / Армстронг Майкл. - М.: ИНФРА-М, 2002. - 328 с.

5. Корнелиус H. HR-менеджмент: поиск, подбор, треннинг, адаптация, мотивация, дисциплина, этика. / Н. Корнелиус - Д. : Баланс Бизнес-Бук, 2005. - 520 с.

6. Збрицька Т. П. Управління розвитком персоналу: навч. посіб. / Т.П. Збрицька, Г.О. Савченко, М.С. Татаревська. - Одеса: Атлант, 2013. - 427 с.

7. Книш П. Сучасні концептуальні підходи до управління людськими ресурсами. / П. Книш // Державне управління та місцеве самоврядування. - 2014. - Вип. 3(22) - С. 234244

8. Торрингтон Д. Управление человеческими ресурсами: учебник: пер. с англ. 5-е англ. изд / Д. Торрингтон , Л. Холл, С. Тэйлор. - М.: Дело и сервис, 2004. - 752 с. 
9. Петрова І. Л. Стратегічне управління людськими ресурсами : навч. посіб. / І.Л. Петрова - К. : КНЕУ, 2013. - 466 с

10. Нижник Н. Р. Організаційно-правові засади модернізації публічної служби в Україні. / Н.Р. Нижник // Теорія та практика державної служби: Матеріали наук. практ. конф. (м. Дніпропетровськ, 8 листопада 2013 р.). - Дніпро: ДРІДУ НАДУ, 2013. - С.7-10

11. Osborne, D Reinventing Government: How the Entrepreneurial Spiritis transforming the Public Sector, / D. Osborne, T. Gaebler. - Reading, Mass., Adison Wesley. 1992. - 427 p.

12. Линдюк О. А. Теорія та практика модернізації державної служби України в умовах глобалізації: монографія. / О.А. Линдюк - Київ : НАДУ, 2016. - 304 с.

13. Бертуччі Г. Розкриття людського потенціалу для підвищення ефективності державного сектору: міркування щодо головних висновків Всесвітньої доповіді UNDESA'S 2005 про стан державного сектору. / Г. Бертуччі // Демократичний розвиток: вищі державні службовці та політико-адміністративні стосунки: Матеріали 18 Міжнар. конгресу з підготовки вищих держ. службовців України (Київ, 15-17 черв. 2005 р.) -К.: K.I.C., 2005. - C. 146

\section{References:}

1. Balabanova L. V., Sardak O. V. (2011) Upravlinnia personalom [Personnel Management]. Kyiv: TsUL. [in Ukrainian].

2. Pliachkaitene Y. M. (2011) Stanovlenye i razvitie teorii chelovecheskoho kapitala. [Formation and development of the theory of human capital] Molodyi uchenyi. - Young scientist, 7, t. 1., 102-104 [in Ukrainian].

3. Deiv Ulrykh. (2006) Effektyvnoe upravlenie personalom: novaia rol HRmenedzhera v orhanyzatsyy. [Human Resource Champions: The Next Agenda for Adding Value and Delivering Results]. M.: «Viliams». [in Ukrainian].

4. Armstronh Maikl. (2002) Stratehycheskoe upravlenye chelovecheskymy resursamy [Strategic Human Resource Management]. M.: YNFRA-M. [in Ukrainian].

5. Kornelyus N. (2005) NR-menedzhment: poysk, podbor, trennynh, adaptatsyia, motyvatsyia, dystsyplyna, etyka [HR management: search, selection, training, adaptation, motivation, discipline, ethics]: Balans Byznes-Buk. [in Ukrainian].

6. Zbrytska T. P., Savchenko H. O., Tatarevska M. S. (2013) Upravlinnia rozvytkom personalu [Personnel development management]. Odesa: Atlant. [in Ukrainian].

7. Knysh P. (2014) Suchasni kontseptualni pidkhody do upravlinnia liudskymy resursamy. [Modern conceptual approaches to human resource management] Derzhavne upravlinnia ta mistseve samovriaduvannia - Public administration and local-self government, 3(22), 234-244 [in Ukrainian].

8. Torrynhton D., Kholl L., Teilor S. (2004) Upravleniye chelovecheskimi resursami. [Human resource management]. M.: Delo y servys. [in Ukrainian].

9. Petrova I. L. (2013) Stratehichne upravlinnia liudskymy resursamy [Strategic human resource management]. K. : KNEU.[in Ukrainian].

10. Nyzhnyk N. R. (2013) Orhanizatsiino-pravovi zasady modernizatsii publichnoi sluzhby v Ukraini.[Organizational and legal bases of public service modernization in Ukraine] Proceedings of the Conference (m. Dnipropetrovsk, 8 lystopada 2013 r.): nauk. prakt. konf. "Teoriia ta praktyka derzhavnoi sluzhby" - The Conference "Theory and practice of public service”. (p.7-10). Dnipro: DRIDU NADU [in Ukrainian].

11. Osborne, D and Gaebler, T. (1992).Reinventing Government: How the Entrepreneurial Spiritis transforming the Public Sector, Reading, Mass., Adison Wesley [in English].

12. Lyndiuk O. A. Teoriia ta praktyka modernizatsii derzhavnoi sluzhby Ukrainy $\mathrm{v}$ umovakh hlobalizatsii (2016) [Theory and practice of modernization of the civil service of Ukraine in the context of globalization]. Kyiv : NADU. [in Ukrainian]. 
13. Bertuchchi H. (2005) Rozkryttia liudskoho potentsialu dlia pidvyshchennia efektyvnosti derzhavnoho sektoru: mirkuvannia shchodo holovnykh vysnovkiv Vsesvitnoi dopovidi UNDESAS 2005 pro stan derzhavnoho sektoru.[ Unlocking the human potential to improve public sector efficiency: reflections on the main findings of the 2005 UNDESA'S World Report on the Public Sector]. Proceedings of the Conference: Mizhnar. konhres $\mathrm{z}$ pidhotovky vyshchykh derzh. Sluzhbovtsiv Ukrainy "Demokratychnyi rozvytok: vyshchi derzhavni sluzhbovtsi ta polityko-administratyvni stosunky" - International Congress on Civil Service Training of Ukraine "Democratic Development: Reliable Services and PoliticalAdministrative Relations". (p. 146), Kyiv, K.: K.I.S. [in Ukrainian]. 